\title{
ドープモリブデンの低温破断特性に及ぼす試験片厚さおよび試験方法の影響
}

\author{
星加 哲志, 平岡 裕
}

岡山理科大学大学院理学研究科, ₹ 700-0005 岡山市理大町 1-1.

\section{Influence of Specimen Thickness and Test Method on Low-Temperature Fracture Characteristics in Doped Molybdenum}

\author{
Tetsuji Hoshika and Yutaka Hiraoka \\ Graduate School of Science, Okayama University of Science, 1-1 Ridai-Cho, Okayama 700-0005.
}

Received June 29, 1998

\section{SYNOPSIS}

In order to evaluate the strength and ductility of a material whose size and shape are limited, it is quite valid to apply the bend tests by using miniaturized specimens. In this study bend tests and tensile tests were performed for doped molybdenum with an elongated grain structure. Then influence of specimen thickness and test method on the low-temperature strength and ductility was discussed. In this study the fracture strength and ductility particularly at low temperatures were represented by two parameters, critical stress and critical temperature respectively.

Results are summarized as follows. First, influence of specimen thickness ranging $0.5-1.0 \mathrm{~mm}$ on the critical stress and critical temperature was not recognized for doped molybdenum with an elongated grain structure. Secondly, relationship between yield strength $\left(\sigma_{\mathrm{yt}}\right)$ by tensile tests and that $\left(\sigma_{\mathrm{yb}}\right)$ by bend tests was $\sigma_{\mathrm{yt}}=\sigma_{\mathrm{yb}} / 1.74$ for doped molybdenum with an elongated and very large grain structure.

KEY WORDS

doped molybdenum, specimen thickness, test method, critical stress, critical temperature

\section{1 緒言}

一般的にモリブデンは再結晶組織になると材料が著しく脆く なる("再結晶脆化").このような材料の研究開発において, 強 度および延性等の機械的性質を評価することは必要不可欠であ る.しかしながら，試験に供する材料のサイズおよび形状がし ばしば制約される。例えば栗下ら ${ }^{1,2}$ は，MA法と HIP 法を利用 して炭化チタン (TiC), 炭化ハブニウム(HfC)等の炭化物を分散 させたモリブデン合金を開発した.これらの合金はTZM合金 に比べて高い再結晶温度および良好な低温勒性を示したが、製 造上,試料のサイズが制限された。つぎにいわゆる長大粒組織 を有したドープモリブデンの場合,通常市販されているものは 薄板および細線であり,製造可能な試料の形状が制限されてい る.また中性子照射を受けた材料の機械的性質を評価する場 合，技術面および安全面から，できるだけ小さいサイズの試験 片を用いて行うことが要求される.さらに, 以上のようにして サイズおよび形状の点で制約を受けるような材料に対しては， 試験片加工が容易・安価であり，また治具への試験片のセット が簡便である曲げ試験が有効かつ適切な試験方法であると考え
られている。

これまでわれわれは，等軸粒組織を有したモリブデン材料に 対して,曲げ試験による強度および延性に及ぼす試験片サイズ の影響を調べてきた.その結果，平均結晶粒径約 $25 \mu \mathrm{m}$ の純モ リブデン再結晶板の場合, 試験片幅が $1 \sim 4 \mathrm{~mm}$, 試験片厚さが 0.5 1mm の範囲内で，曲げ強度および延性に及ぼす試験片サ イズの影響は無視できることを明らかにしだ)。また，このよ うな等軸粒組織を有した純モリブデンおよびモリブデン合金の 場合,引張試験により得られる強度と曲げ試験により得られる 強度の間につぎのような経験式が成り立つことを明らかにしだ).

$$
\sigma_{\mathrm{yt}}=\sigma_{\mathrm{yb}} / 1.74
$$

$\sigma_{\mathrm{yt}}$ と $\sigma_{\mathrm{yb}}$ はそれぞれ引張試験と曲げ試験により得られる降伏強 度である.なお最大強度についても, 後述するように降伏強度 と最大強度が等しくなるような温度付近で, 同様につきの式が 成り立つものと推察した。

$$
\sigma_{m}=\sigma_{m b} / 1.74
$$


$\sigma_{\mathrm{m}}$ と $\sigma_{\mathrm{mb}}$ はそれそれ引張試験と曲げ試験により得られる最大 強度である。

一方長大粒組織を有したドープモリブデンの場合, 試験片 幅が 2 4mm の範囲内では曲げ強度に及ぼす試験片幅の影響 はほとんど認められなかった5). しかしながら,このような粒 組織を有したモリブデン材料において, 曲げ強度および延性 に及ぼす試験片厚さの影響, 曲げ試験と引張試験により得ら れる強度の相関性については不明である.そこで本研究では, ランタン酸化物を分散させて作製したドープモリブデンを用 いて, 液体窒素温度から室温までの範囲で曲げ試験および引 張試験を行った.そして,特に低温域での強度および延性に及 ぼす試験片厚さおよび試験方法の影響について検討を行った。

\section{2 実験方法}

試験片厚さの影響を調べるために用いた材料は, ランタン 酸化物を約 $0.7 \mathrm{~mol} \%$ 添加し, 加工度を変えて作製した 2 種類 のドープモリブデン板 (初期板厚約 $1 \mathrm{~mm}$ )であった. 本材料よ り, 試験片の長手方向と板の最終圧延方向が平行になるよう に曲げ試験片 (Fig.1(a)) を切り出した.そして試験片の片面だ けを研削除去して, 最終板厚が $0.7 \mathrm{~mm}$ および $0.5 \mathrm{~mm}$ のものを 得た. 一方, 引張試験と曲げ試験による強度の相関性を調べ るために用いた材料は, 同じくランタン酸化物を約 $0.7 \mathrm{~mol} \%$ 添加して作製したドープモリブデン板 (初期板厚約 $0.5 \mathrm{~mm}$ )で あった. 本材料より, Fig.1に示すような形状・サイズの曲げ 試験片 (Fig.1(a)) および引張試験片 (Fig.1(b)) を切り出した.

すべての試験片に対して電解研磨を施した後, 約 $1.3 \times 10^{-4}$ $\mathrm{Pa}$ の真空中, $2373 \mathrm{~K} \times 3.6 \mathrm{ks}$ の条件で再結晶熱処理を行った. 熱処理後の粒組織(粒径, 粒形)は光学顕微鏡を用いて調べた. Fig.2は試験片厚さの影響を調べるために用いた2種類の材料 に対する組織写真である. 一つは最終圧延方向に平行に著し く伸びた粗大粒組織 (本研究で "Sample-L" あるいは "L材 " と する)である. 平均結晶粒径は, 試験片の幅方向に500 $600 \mu \mathrm{m}$, 厚さ方向に約 $100 \mu \mathrm{m}$ であった. また, この粗大粒の

(a) Bend-test specimen

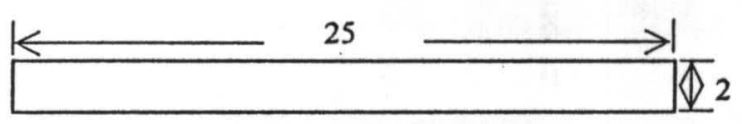

(b) Tensile-test specimen

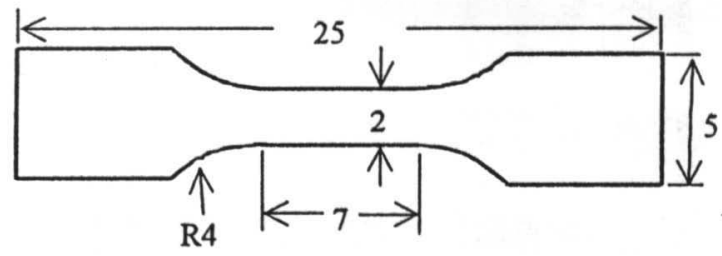

(mm)

Fig.1 Size and shape of the specimen for bend tests (a) and tensile tests (b).
粒内および粒界に数 $10 \mu \mathrm{m}$ の細粒が散在しているのを確認し た.他の一つは細長く伸びているが比較的細粒組織(本研究で "Sample-S" あるいは "S 材 "とする)であった．平均結晶粒径 は, 試験片の幅方向に約 $40 \mu \mathrm{m}$, 厚さ方向に約 $25 \mu \mathrm{m}$ そして長 手方向に約 $125 \mu \mathrm{m}$ であった.一方, 試験方法の影響を調べる ために用いた材料の粒組織は, L材とほぼ同様であった。

以上のようにして用意した試験片を用いて, 引張試験およ び曲げ試験を行った. 特に試験片厚さの影響を調べるための 曲げ試験の場合, 表面近くの粒組織を同等にする目的で, 研 削除去処理を施していない面に最大引張応力が印加するよう に試験片を治具にセットした。試験温度は, 曲げ試験では液 体窒素温度から室温の範囲で, また引張試験では約153Kから 室温までの範囲であった.さらにつきの式を用いて初期ひず み速度を $1.2 \times 10^{-3} \mathrm{~s}^{-1}$ にした。

$$
\begin{aligned}
& \dot{\varepsilon}_{\mathrm{t}}=v / l_{0} \\
& \dot{\varepsilon}_{\mathrm{b}}=6 t v /(2 a)^{2}
\end{aligned}
$$

$v$ はクロスヘッド速度 $\left(\mathrm{mm} \cdot \mathrm{s}^{-1}\right) て ゙, \dot{\varepsilon}_{1}$ と泉はそれぞれ引張試験 と曲げ試験における初期ひずみ速度である.loは試験前におけ る引張試験片の平行部長さ $(=7 \mathrm{~mm})$ で, $t$ と $2 a$ はそれそれ試験 片厚さ $(\mathrm{mm})$ と曲げ試験治具の支持ピン間距離 $(=16 \mathrm{~mm})$ であ る. 引張試験による強度 $\left(\sigma_{i}\right)$ と曲げ試験による強度 $\left(\sigma_{b}\right)$ はそ
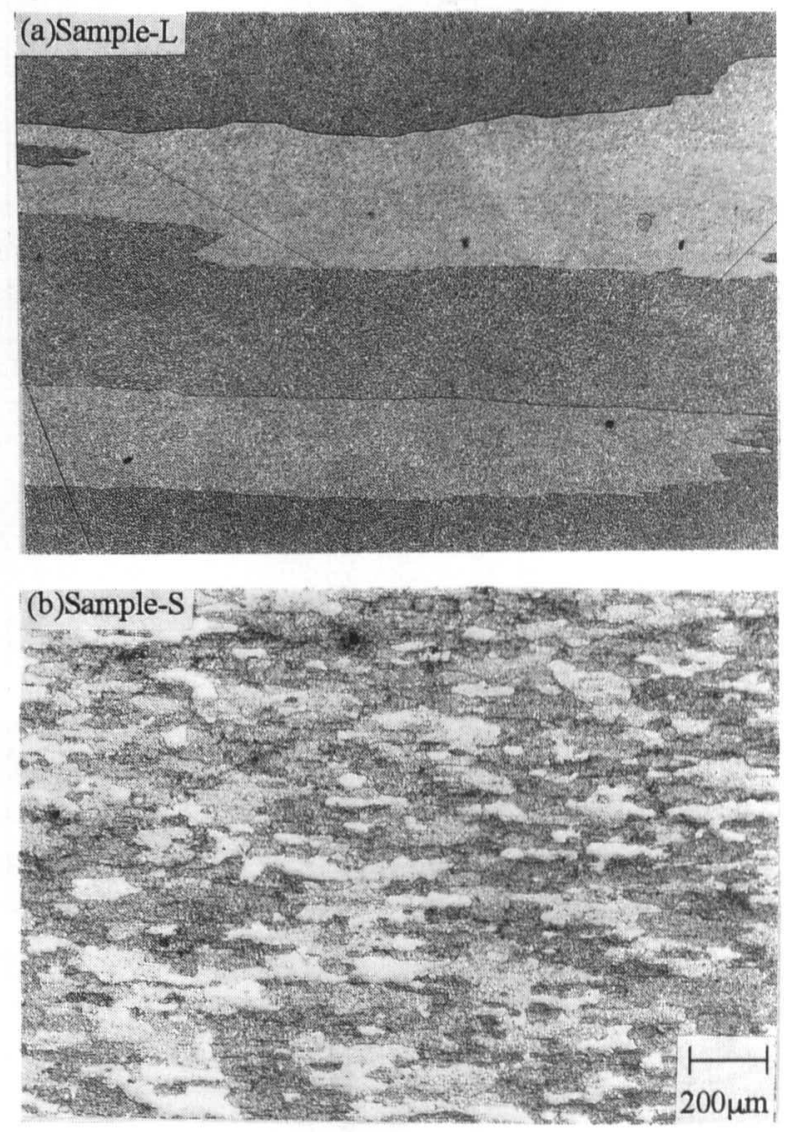

Fig.2 Typical optical micrographs of doped molybdenum after recrystallization. 
れそれつきの式により算出した。

$$
\begin{aligned}
& \sigma_{\mathrm{t}}=P l / A_{0} l_{0} \\
& \sigma_{0}=3 a P / w t^{2}
\end{aligned}
$$

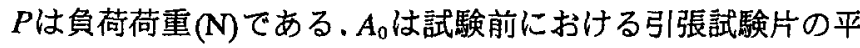
行部断面積 $\left(\mathrm{mm}^{2}\right)$ で, l は試験後における試験片平行部の長さ $(\mathrm{mm})$ である．また $w$ は曲げ試験片の幅 $(\mathrm{mm})$ である.

\section{3 結果および考察}

\section{1 試験片厚さの影響}

本研究では，低温における破断強度と延性をそれそれれ臨界 応力と臨界温度という二つのパラメータで代表させた．臨界 応力と臨界温度は，Fig.3に模式的に示すように，降伏強度と 最大強度の温度依存性から実験的に決定される6.7). 降伏強度 は試験温度の低下とともに顕著に增加する。一方最大強度は， 比較的高い温度域において降伏強度と同様に温度低下ととも に增加するか，低温域ではあまり大きな変化を示さない。こ こで降伏強度と最大強度が等しくなるような温度を臨界温度

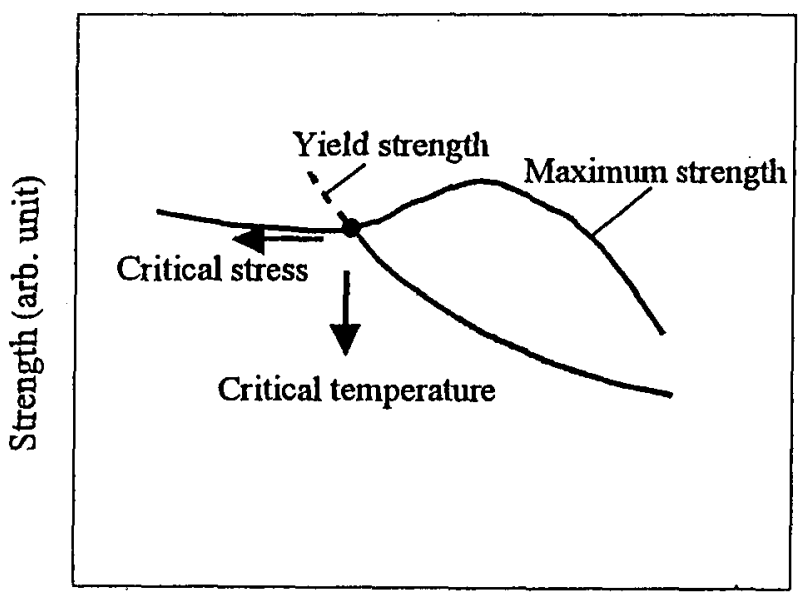

Test temperature (arb. unit)

Fig.3 Definition of critical stress and critical temperature.

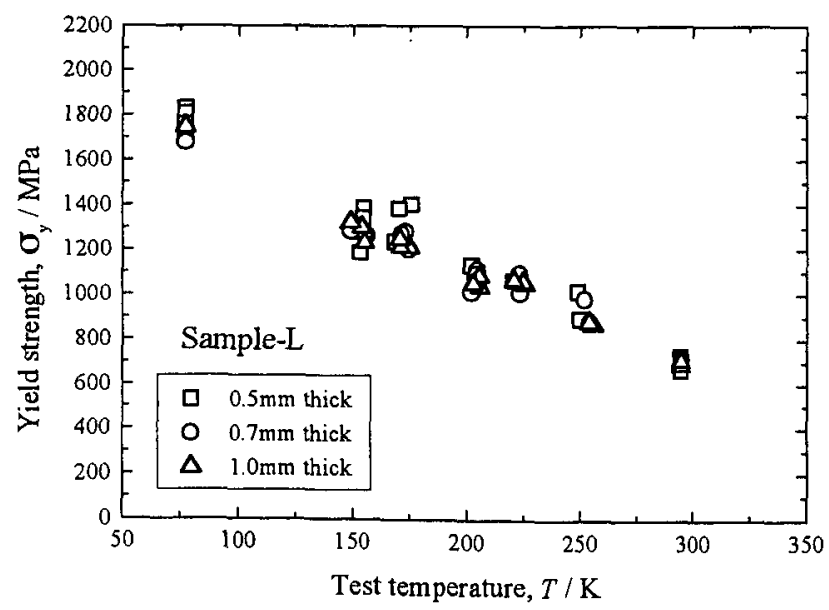

Fig.4 Yield strength as a function of test temperature for sample-L.
とし，その温度における強度を臨界応力と定義する．臨界応 力は，一般的に試験片の最も弱い部分に微小龟裂が発生し， それが粒界あるいは粒内を伝播する時の応力である. 比較的 細粒の等軸粒組織の場合，臨界応力は"粒界の破断強度"に対 応する”。.また図より，臨界応力は臨界温度付近またはそれ以 下の低温域において，ほぼ最大強度に等しいことがわかる。 しかしながら本研究で用いるドープモリブデンのように長大 粒組織の場合, 臨界応力は"粒内の破断強度"に対忍すると考 えられる ${ }^{8)}$. 一方臨界温度は, 試験片がほとんど塑性変形を示 さずに破断する温度であり，いわゆる"延性一脆性遷移温度" である.また臨界温度の逆数は材料の低温における延性を表 す7).

Fig.4 と Fig.5はそれそれ L材における降伏強度と最大強度 の温度依存性である．降伏強度圾試験温度の低下とともに增 加したが, 試験片厚さの違いによる差はほとんど認められな かった.一方最大強度は, 約173K以下の低温では試験片厚さ の違いによる差は認められず，また温度依存性がほとんどな かった. なお約223K以上の温度で, 最大強度は試験片厚さが 小さくなるほど低くなる傾向を示したが, 理由は現在のとこ ろ不明である.つきに Fig.6と Fig.7はそれそれ S材における 降伏強度と最大強度の温度依存性である。降伏強度は, L材と 同様に，試験温度の低下とともに増加しまた試験片厚さの違 いによる差がほとんど認められなかった。一方最大強度につ いても，約 223K以上の温度域を除いて，L材と同様に試験片 厚さの違いによる差はほとんどなかった.

L材およびS 材における臨界忍力に及ぼす試験片厚さの影 響を Fig.8に示した。また，L材およびS材における臨界温度 に及ぼす試験片厚さの影響を Fig.9に示した. なお，比較のた め, 図中に等軸粒組織を有した純モリブデンの結果 ${ }^{3}$ を示し た. L材， $\mathrm{S}$ 材ともに，純モリブデンと同様に，0.5 1 $1 \mathrm{~mm} の$ 籁囲において臨界応力および臨界温度に及ぼす試験片厚さの 影響は認められなかった。これらの結果は以下のとおり説明 される. 液体窒素温度で破断した L材の破面観察を行ったと ころ，いずれの試験片でも破壊は同程度の大きさの細かい等

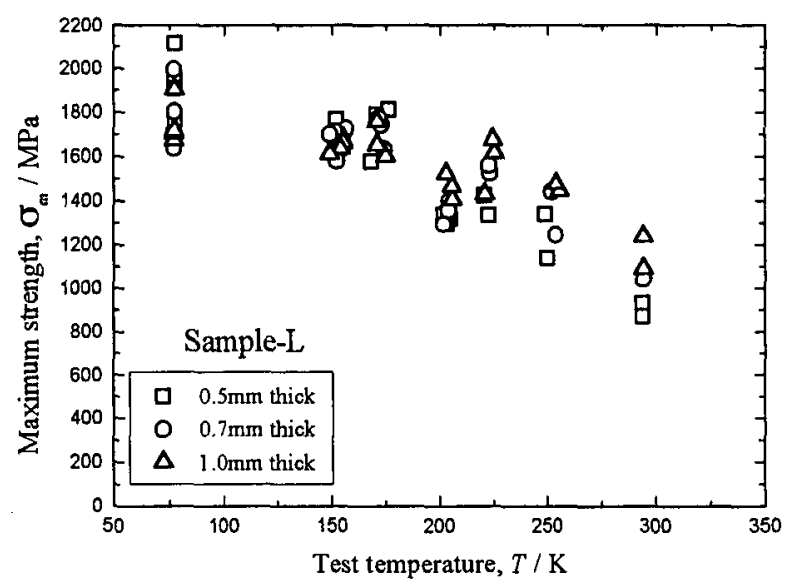

Fig.5 Maximum strength as a function of test temperature for sample-L. 


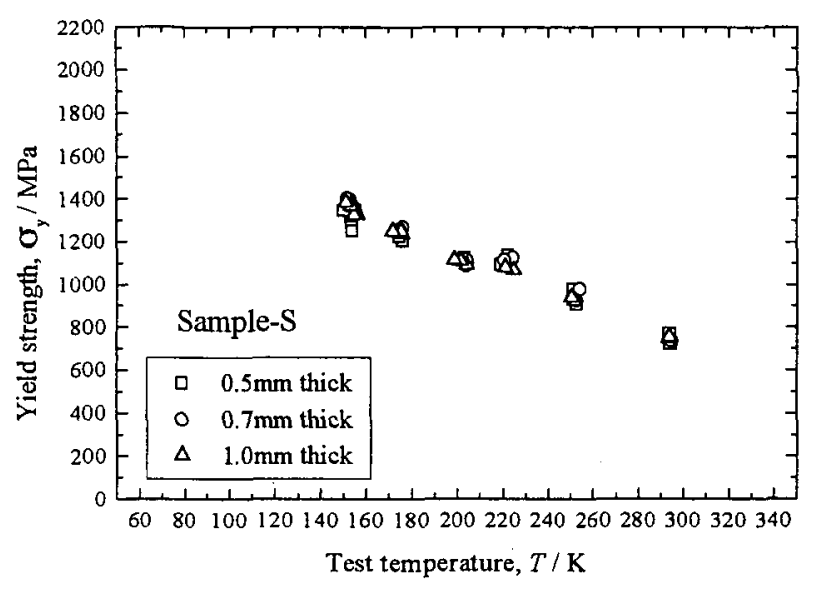

Fig.6 Yield strength as a function of test temperature for sample-S.

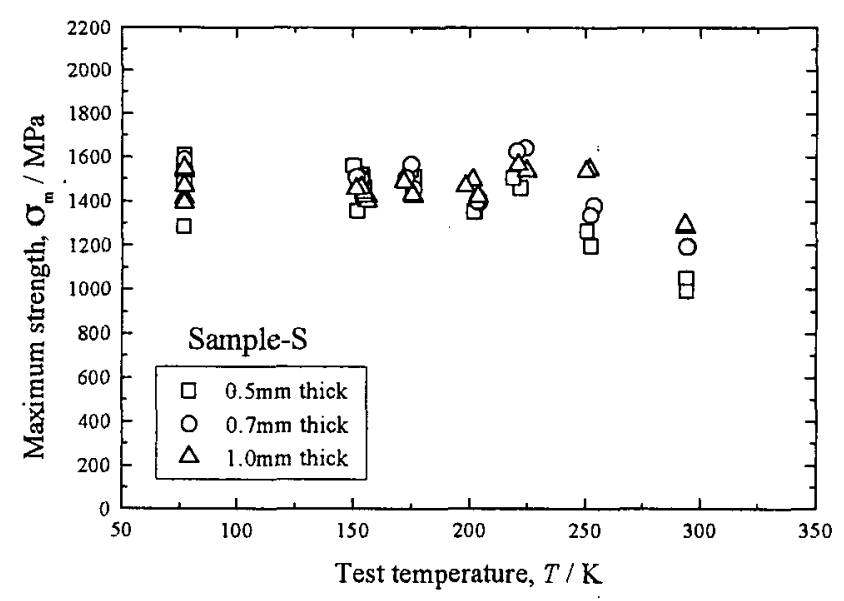

Fig.7 Maximum strength as a function of test temperature for sample-S.

軸粒より開始し，その後粗大粒の内部を伝播していた。例え ば全破断面に占める粒界破面の割合は，試験片厚さに関係な くほぼ0\%であった.L材のように長大粒組織を有した材料の 場合，臨界応力は粒内の破断強度に対応し，また破壊の開始 点となった細粒のサイズに依存する ${ }^{8)}$. 破面観察により試験片 厚さに関係なく破断様相が同様であったことにより，臨界応 カに違いが認められなかったものである。つきに臨界温度は すでに述へたように降伏強度と最大強度(臨界応力にほぼ等し い)の両者により決定される. 本研究において，0.5〜 $1 \mathrm{~mm}$ の 範囲で降伏強度に及ぼす試験片厚さの影響はほとんどなかっ た.一般的に 1 個の結晶粒が変形するとき,その周りの結晶 粒も同時に変形しなければならない。これが変形に対する拘 束力となり，降伏強度に試験片厚さ依存性が現れる ${ }^{9,10)}$. しか しながら L 材の場合, 試験片の厚さ方向の粒径は試験片の厚 さ $(0.5 \mathrm{~mm} \sim 1.0 \mathrm{~mm})$ と比べて相対的に非常に大きい.このため 変形に対する拘東力に差が現れなかったものと解釈される. したがって, 降伏強度および最大強度 (臨界応力) に違いがな く, 結果的に臨界温度にも違いが現れなかったものである.

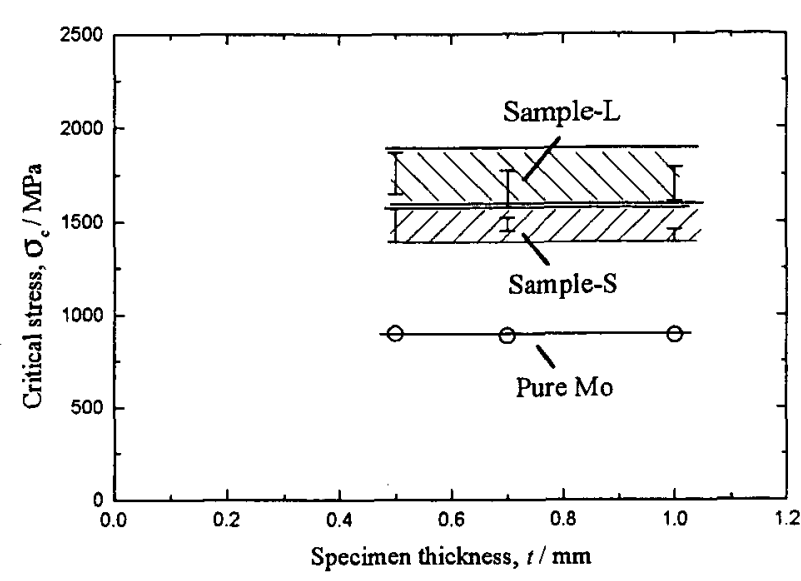

Fig.8 Effect of specimen thickness on critical stress.

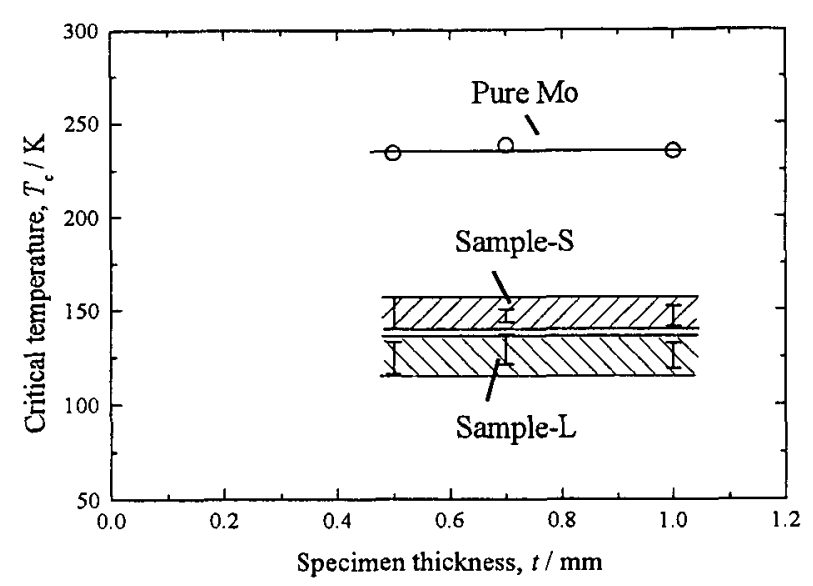

Fig.9 Effect of specimen thickness on critical temperature.

一方 $\mathrm{S}$ 材の破面観察を行ったところ，破壊は細長く伸びた結 晶粒より開始し，その後主としてこれらの結晶粒の内部を伝 播していた. 全破面に占める粒界破面の割合を算出してみる と, $12 \%(0.5 \mathrm{~mm}$ 厚 $), 10 \%(0.7 \mathrm{~mm}$ 厚 $), 10 \%(1.0 \mathrm{~mm}$ 厚 $)$ とな り，同等であった。このように試験片厚さに関係なく破断様 相がほぼ同様であったことから, 臨界応力に違いが現れな かったものと推察される.つきに臨界温度について以下のと おり解釈された. S 材の平均結晶粒径は試験片の厚さ方向に $25 \mu \mathrm{m}$ であり，等軸粒組織を有した純モリブデンと同等であ る.純モリブデンの場合, 試験片厚さが $0.5 \sim 1 \mathrm{~mm}$ の範囲にお いて，降伏強度が同等であることが報告されている ${ }^{3)}$. した がって，S材の場合も同様に，降伏強度に試験片厚さ依存性が 現れなかったものと考えられる．このようにして降伏強度お よび最大強度 (臨界応力)に違いがなく, 結果的に臨界温度に も違いが現れなかったものである。

L材の臨界応力はS材に比べて全体的に高く，また臨界温度 は全体的に低かった。この違いは，両材料における破壊の開 始点サイズが同程度である点を考慮すれば，伝播経路の違い に起因したものと考えれる.すなわちS材の場合, 粒界破面 
率がL材に比べて大きく，破壊の伝播に対する抵抗力が小さ い.このため最大強度すなわち臨界応力が小さくなった。臨 界温度については，両材料において降伏強度にほとんど差か なかったことより,主として最大強度の違いによって説明され る.

\section{2 試験方法の影響}

Fig.10は, L材と同様の長大粒組織を有したドープモリブデ ンに対して，曲げ試験により得られた降伏強度を引張試験に より得られた降伏強度に対してプロットしたものである。 デー夕点の添字は試験温度を示す。ここで試験片厚さが

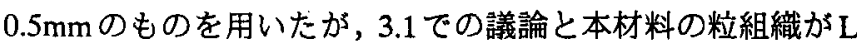
材と同様である点を考虑すれば，強度に及ぼす試験片サイス の影響は無視できる.図中に比較的細かい等軸粒組織を有し た純モリブデンおよびモリブデン合金に対して得られた直線 関係 ${ }^{4)}$ 示した、デー夕数は少ないが, 今回の長大粒組織を有 したドープモリブデンの結果も傾き 1.74 の直線関係に大体一 致することが明らかである. 本研究の結果およびこれまでの 結果 ${ }^{4}$ を考え合わせると，曲げ試験と引張試験による強度の 違いは，粒組織にほとんど無関係であると結論される．また 最大強度についても，等軸粒組織を有したモリブデン材料と 同じく，臨界温度付近では降伏強度と同様の挙動をするもの と推察できる.したがって，(1)式と同様の関係式((2) 式)が 成り立つものと推察される。

曲げ試験により得られた降伏強度および最大強度の値を用 いて(1)および (2)式より引張試験に換算した臨界応力および 臨界温度を算出したところ，臨界応力 $1030 \sim 1090 \mathrm{MPa}$ ，臨界 温度 120〜130K が得られる。

\section{4 ま と め}

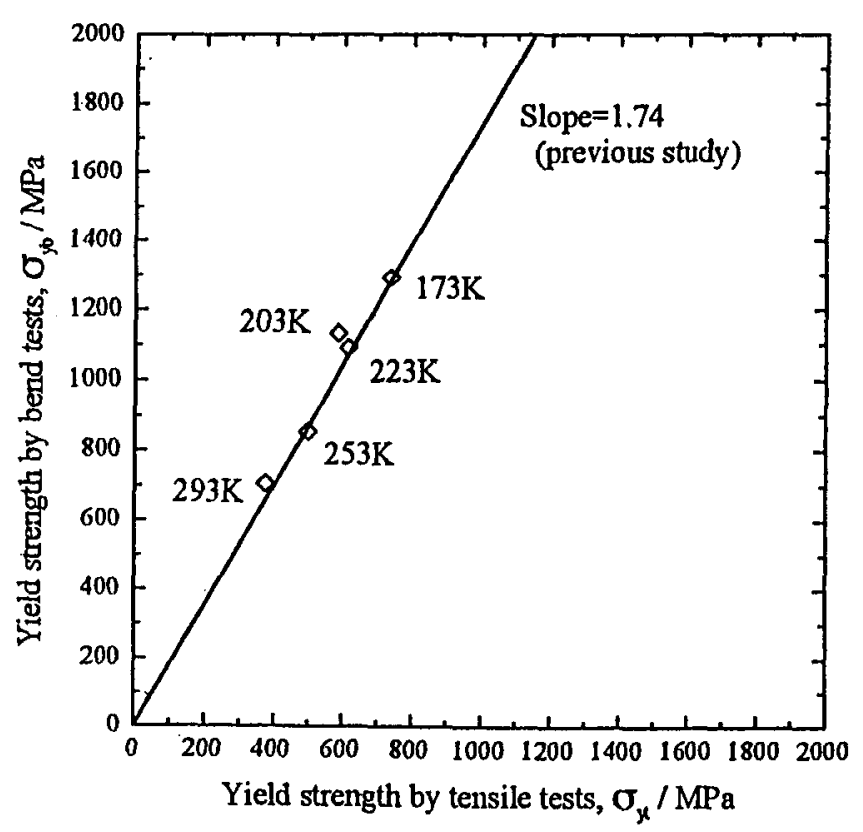

Fig.10 Plots of yield strength by bend tests against that by tensile tests.
（1）著しく伸びた粗大粒組織および細長く伸びた細粒組織を有 したドープモリブテンにおいて，臨界応力および臨界温度 に及ぼす試験片厚さ $(0.5 \sim 1 \mathrm{~mm}$ の範囲)の影響はほとんど なかった.この結果は, 低温域において最大強度および降 伏強度ともに試験片厚さ依存性がほとんどなかったことに より説明される。

(2) 著しく伸びた粗大粒組織を有したドープモリブテンにおい て,引張試験および曲げ試験により得られた降伏強度の間 に次の関係式が成り立った。

$$
\sigma_{y 1}=\sigma_{y b} / 1.74
$$

また本結果は，上記の関係式が粒組織の違いに関係なく成 り立つことを示唆するものである.

\section{謝 辞}

本研究において用いたドープモリブデンは東京タングス テン侏により提供されたものである.ここに謝意を表します。 材料の熱処理および破面観察については，岡山セラミックス 技術振興財団・研究所の設備を利用させていたたいた。

\section{文献}

1) H.Kurishita, Y.Kitsunai, Y.Hiraoka, T.Shibayama and H.Kayano: "Development of Molybdenum Alloy with High Toughness at Low Temperatures", Mater. Trans., JM, 37(1996)89-97.

2) M.K.Yoo, Y.Hiraoka, H.Kurishita, H.Kayano and J.Choi: "Recrystallization of TiC Dispersion Mo-Alloy", Int. J. Refr. Met. \& Hard Mater., 14(1996)355-364.

3）平岡裕, 星加哲志: "純モリブデン再結晶板の延性一脆性遷 移特性に及ぼす試験片寸寸法の影響", 粉体および粉末冶金, 42(1995)108-112.

4) T.Hoshika, S.Yoshimura and Y.Hiraoka: "Evaluatinon of LowTemperature Fracture Characteristics of Molybdenum by Means of Tensile Tests and Bend Tests", Proc. of 14th Int. Plansee Sem., Reutte/Tirol, (1997)p.1018-1025.

5) Y.Hiraoka, T.Hoshika, M.K.Yoo and J.Choi: "Specimen Size Effect on Bend Properties of Molybdenum Doped with Potassium-Silicate", 粉体および粉末治金, 42(1995)964-968.

6) Y.Hiraoka: "Significant Effect of Carbon Content in the LowTemperature Fracture Behavior of Molybdenum", Trans. JIM, 31(1990)861-864.

7) Y.Hiraoka and S.Yoshimura: "Effect of Complex Additions of Re or Ti with C on the Strength and Ductility of Recrystallized Molybdenum", Int. J. Refr. Met. \& Hard Mater., 12(19931994)261-268.

8) Y.Hiraoka and T.Hoshika: "Parameter Representing LowTemperature Fracture Strength in Molybdnum Having an Elongated and Large Grain Structure", Int. J. Refr. Met. \& Hard Mater., (1998) submitted

9) S.Miyazaki, K.Shibata and H.Fujita: "Effect of Specimen 
Aggregates with Various Grain Sizes", Acta metall., 27(1979) 855-862.

10) K.Miyahara, C.Tada, T.Uda and N.Igata: "The Effects of Grain and Specimen Sizes on Mechanical Properties of Type 316 Austenitic Stainless Steel", J. Nucl. Mater., 133-134(1985)506510. 